\title{
Relationship of Exogen Variables for Customer Use and Satisfaction of Delivery Services
}

\author{
Minto Waluyo ${ }^{{ }^{*}}$, Yekti Condro Winursito ${ }^{1}$, Mega Cattleya Prameswari Annissaa Islami $^{1}$, Rizqi Novita Sari ${ }^{1}$, \\ Mohammad Rachman Waluyo ${ }^{2}$ \\ ${ }^{1}$ Department of Industrial Engineering, Faculty of engineering. University of Pembangunan Nasional Veteran Jawa Timur, Surabaya, \\ Indonesia \\ ${ }^{2}$ Department of Industrial Engineering, Faculty of engineering. University of Pembangunan Nasional Veteran Jakarta, \\ Indonesia
}

\begin{abstract}
The purpose of this paper is to determine the relationship of exogenous variables consisting of quality logistics service variables, brand image, and social media marketing on usage decisions and customer satisfaction. The shipping services studied specifically for domestic shipments consisted of J\&T, JNE, TIK1, Wahana, SiCepat, ID Express, and Pos Indonesia using perception data through questionnaires. Respondents have at least used delivery services twice. Determination of the number of respondents using the maximum likelihood technique. The tool used in this research is Structural Equation Modeling. The results of this study indicate that the variables of logistics service quality and social media marketing have a positive and significant effect on usage decisions. The relationship between brand image and usage decisions cannot be proven because there is multicollinearity, which causes this variable to be excluded from the study. The equation of the relationship model of exogenous variables on the use and customer satisfaction of expedition services without using the brand image variable is as follows, $\mathrm{Y} 2=0.371 \mathrm{X} 1+0.482 \mathrm{X} 3$.
\end{abstract}

Keyword: Exogen Variables, Delivery Services, Structural Equation Modeling

\section{Introduction}

The goods delivery industry in the pandemic era is growing very rapidly [1]. This is only to answer health protocols. This growth is supported by the ease of technology, information, and the rapid development of e-commerce. Indonesia has the largest population in Southeast Asia, this indicator is a promising market share. A large number of millennial populations causes online shopping activities to become an alternative to meet the needs of life. The goods delivery service industry will continue to grow along with the shift in consumer behavior who prefers to shop through ecommerce.

Several companies that provide expedition services, among others, research that has been done are J\&T, JNE, TlK1, Wahana, SiCepat, ID Express, and Pos Indonesia. Freight forwarding companies are competing to attract customers' hearts. Several things the company does to compete with others include maintaining the best service, a good brand image, and massive promotions. In the current era, the loyalty variable has begun to fade because shipping companies are always innovating so that service remains excellent. Customer behavior in choosing delivery services has changed due to intense competition between companies. Changes in customer behavior make many researchers have research space to find information about what variables affect usage decisions, et and customer satisfaction. Rosyada. et. al. (2020) states that expedition service providers can use LSQ (Logistic Service Quality) as a tool to find out customer desires to improve service quality. Several previous studies such as that conducted by [2] stated that service quality and price had a positive and significant effect on the decision to use JNE Freight Forwarding Services. [3] states that service quality, brand image, and price have a positive and significant effect on the decision to use Delivery Services.

Research conducted by [4] states that price and service quality have a positive and significant effect on decisions to use freight forwarding services. [5] states that brand image and service quality variables have a positive and significant effect on service purchasing decisions. The results of research conducted by [6] state that social media marketing has a positive and significant effect on purchasing decisions. [7] examines the influence of brand image, product quality, and price perception on the decision to use JNE courier services and states that there is an important influence between brand image and service use decisions, which means

\footnotetext{
* Corresponding author: mintow.ti@upnjatim.ac.id
} 
that brand image has a direct close relationship with usage decisions and has an influence real. [8] state that service quality and brand image variables have a significant effect on customer satisfaction, and customer satisfaction has a significant effect.

The purpose of this research is to analyze the equation of the mathematical model and determine the relationship between the variables of logistics service quality, brand image, and social media marketing on usage decisions and customer satisfaction, which focuses on consumers who choose to shop through ecommerce. The relationship of exogenous variables to the use and satisfaction of shipping service customers can be seen in Fig. 1 .

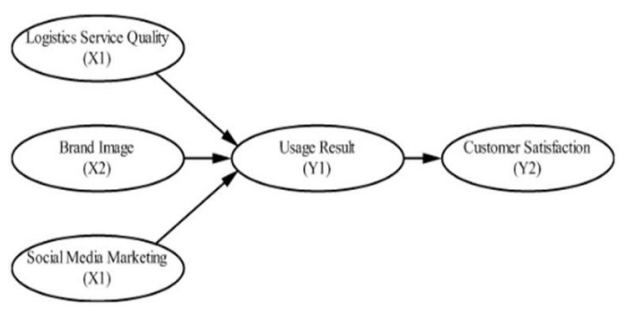

Fig. 1. Research model of the relationship of exogenous variables to the use and customer satisfaction of expedition services.

\section{Literary Reviews}

\subsection{Logistics service quality}

Service quality is not only assessed from the company's point of view but must meet consumer demands and expectations $[9 ; 10]$. Logistics Service Quality is the development of service quality that aims to measure customer satisfaction in logistics or goods delivery. The better the quality of logistics services, the more customer satisfaction will increase. Consumer satisfaction will affect the continuity of delivery service providers [8]. According to [11] and [5], service quality is an attitude that results from comparing consumer service quality expectations with the company's performance perceived by consumers. Service quality has been a frequently researched theme in marketing research and logistics research since the mid-1980s, in line with research interests in the field of quality management and satisfaction in companies [12].

Quality of Logistics Service is an effort made by the company in meeting the needs and desires of consumers by optimizing the network of goods and services so that they can arrive on time so that the expectations of the promised time to consumers are fulfilled $[13 ; 2]$.

\subsection{Brand image}

Brand image is an important concept in researching consumer behavior. The definition of the brand image according to [7] and [14] is a symbol or sign that can help consumers if they want to determine a product or service they want. Brand image is a consumer's perception of a brand $[15 ; 16 ; 10]$. From this explanation, it can be concluded that the brand image is the consumer's image.

\subsection{Social media marketing}

The The Brand and Marketing Institute (BMI) survey results show that most customers make purchases with social media in mind. Data shows that $80 \%$ of customers in Indonesia are heavily influenced by social media in determining what products to buy. We Are Social research states that Indonesian social media users aged 16-64 years spend an average of 3 hours 26 minutes per day. Indonesia is said to have 160 million or $59 \%$ of the total population of Indonesia, active users of social media, $99 \%$ of whom access via mobile phones. We Are Social stated that the social media frequently used throughout 2020 included YouTube with $88 \%$ of users, WhatsApp with $84 \%$ of users, Facebook with $82 \%$ of users, Instagram with $79 \%$ of users, Twitter with $56 \%$ of users, and Line. With $50 \%$ of users. $[17 ; 18 ; 19 ; 20]$ state that social media marketing is a marketing technique using social media as a means to promote a product or service. Social media marketing is a company's business in terms of communicating, promoting, and selling the products or services they offer through internet services $[21 ; 22 ; 23 ; 24]$.

The internet and social media have a significant contribution in the field of marketing [25]. The increasing use of social media will make companies have to adjust their communication model. Many companies change their marketing platform to social media because of the lower cost of using other media like television. Social media, which was originally a means of socializing and entertainment has now shifted into a place to share information [26].

\subsection{Usage Decision}

[27] defines usage decisions as a series of stages in assessing and receiving information or data about brands and considering alternative brands on similar products and services in making decisions to choose brands. In general, customers will experience five stages of the process before making a decision in the fig. 2, which include identifying problems, tracing information or data, evaluating several product options, deciding to use, and behaving after choosing to use [28].

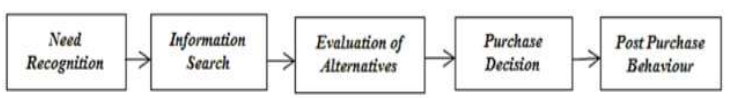

Fig. 2. Five stages of the process before making a decision [28].

\subsection{Customer Satisfaction}

According to [29], customer satisfaction is a person's feelings of pleasure or disappointment that arise after comparing his impression of a product or service with what is expected. The general definition can be 
concluded that customer satisfaction is the impression given by the customer to a product or service after using it. This impression arises because of the comparison of satisfaction obtained.

\section{Research Methods}

The relationship of exogenous variables to the use and customer satisfaction of this expedition service through the steps of the research method as follows. The SEM tool used in this study, the determination of the number of respondents based on the maximum likelihood (ML) technique ranges from 100 to 200 [30], this research data was obtained from distributing questionnaires using a Likert scale (1-5), using probability, Processing of SEM Tool and AMOS Software 23. The processing process is carried out in 4 stages, namely the Measurement Model twice, the first is the initial model, the second after the disposal of the X2 variable, the Structural Model, and the Modified Model, each stage of three stages namely valid, correlation and significance.

\section{Discussion}

\subsection{Data Collection}

The questionnaires in this study were distributed to customers of J\&T, JNE, TIK1, Wahana, SiCepat, ID Express, and Pos Indonesia Delivery Service Providers, with the criteria for filling out the questionnaire that customers had used these services at least twice. The determination of the number of respondents is based on the maximum likelihood (ML) technique, which ranges from 100 to 200 [30]. The results of sampling respondents as many as 155 means that the assumption of SEM with the maximum likelihood (ML) technique is fulfilled.

\subsection{Data Processing (Questionnaire Data Processing}

The results showed that all indicators had a $\mathrm{CR}>2 \mathrm{SE}$ value so that all indicators were declared valid. The significance test uses two approaches $\mathrm{p}<0.05$ and compares the t-table at the 0.05 level with $\mathrm{df}=29$ (sum of all indicators) the t-count value is 1.699 so that all indicators are significant [31].

Exogenous variables with other exogenous variables cannot be significantly correlated from table 1 , then the exogenous variable with the largest significant correlation is discarded (X2) [32]. The results showed that the reliability test obtained all reliable results where the results of construct reliability were more than 0.70 .

Table 1. Correlation Test

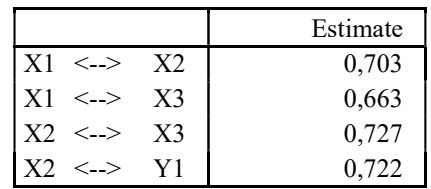

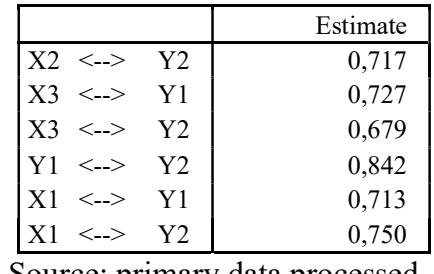

Table 2. Modification Model Validity, Significance and Regression Weight

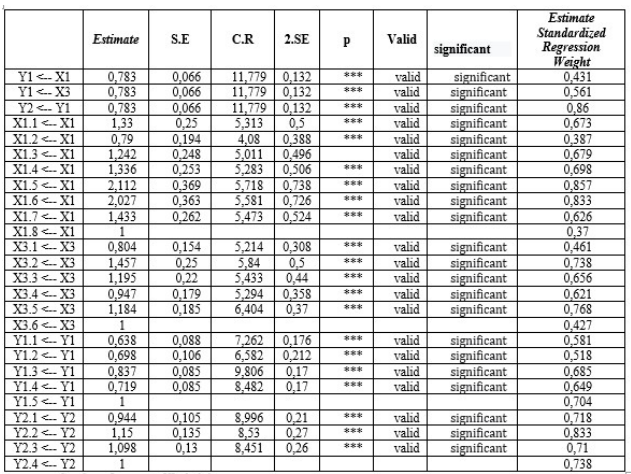

Source: primary data processed

The simultaneous equations of the models in this study are as follows: (Assuming $Z 1$ to $Z 4=0$ and see 3 ) $Y 1=f(X)+Z 3$

$Y 1=f(X 1)+f(X 3)+Z 3$

$Y 1=0.431 X 1+0.561 X 3+Z 3$

$Y 2=f f(Y 1)+Z 4$

$Y 2=0.86(0.431 X 1)+0.86(0.561 X 3)+Z 4$

$Y 2=0.371 X 1+0.482 X 3+Z 4$

a. Hypothesis 1

H1: Quality of Logistics Service has a significant effect on usage decisions.

Based on table 3, the $\mathrm{CR}$ value is 11.779 and the ttable value is 1.714 (tcount $>$ ttable) so that $\mathrm{H} 1$ is accepted where the quality of Logistics Services has a significant effect, with a regression coefficient value of 0.431 on the decision $\mathrm{x}$ use. This means that if the Quality of Logistics Service increases by 1 unit, the decision to use the expedition industry will also increase by 0.431 .

The regression coefficient of 0.431 is smaller than the regression coefficient of social media marketing on the decision to use, but the results of the frequency distribution of "very satisfied" answers are below 70\%.

This shows that the Quality of Logistics Service on the decision to use is very convincing so that management only needs to maintain and improve it. The results of this study are in line with research $[2 ; 3 ; 4 ; 33]$. 
b. Hypothesis 2

$\mathrm{H} 2$ : Brand Image has a significant effect on usage decisions.

This second hypothesis cannot be proven because the Brand Image (X2) variable is excluded from the model because of multicollinearity.

Table 3. Identification of variables and indicator variables

\begin{tabular}{|c|c|c|c|}
\hline $\begin{array}{c}\text { Exogenous } \\
\text { Variable }\end{array}$ & Indicator & $\begin{array}{c}\text { Endogenous } \\
\text { Variables }\end{array}$ & Indicator \\
\hline \multirow{8}{*}{$\begin{array}{l}\text { Logistics } \\
\text { Service } \\
\text { Quality } \\
\text { (X1) } \\
\text { [34] and } \\
\text { [35] }\end{array}$} & $\begin{array}{l}\text { Personal Contact } \\
\text { Quality (X1.1) [34] }\end{array}$ & \multirow{5}{*}{$\begin{array}{c}\text { User } \\
\text { Decisions } \\
\text { (Y1) [28] }\end{array}$} & $\begin{array}{l}\text { Needs Analysis } \\
\text { (Y1.1) [28] }\end{array}$ \\
\hline & $\begin{array}{l}\text { Order Release } \\
\text { Quantity (X1.2) [34] }\end{array}$ & & $\begin{array}{l}\text { Information } \\
\text { Search (Y1.2) } \\
{[28]}\end{array}$ \\
\hline & $\begin{array}{l}\text { Order Procedure } \\
\text { (X1.3) [34] }\end{array}$ & & $\begin{array}{l}\text { Alternative } \\
\text { Evaluation } \\
\text { (Y1.3)[28] }\end{array}$ \\
\hline & $\begin{array}{l}\text { Order Accuracy } \\
\text { (X1.4) [34] }\end{array}$ & & $\begin{array}{l}\text { Decision to Use } \\
\text { (Y1.4) }[28]\end{array}$ \\
\hline & $\begin{array}{l}\text { Order Condition } \\
\text { (X1.5) [34] }\end{array}$ & & $\begin{array}{l}\text { Behaviour After } \\
\text { Using (Y1.5) } \\
{[28]}\end{array}$ \\
\hline & $\begin{array}{l}\text { service for Non- } \\
\text { conformance Orders } \\
\text { (X1.6) [34] }\end{array}$ & \multirow{4}{*}{$\begin{array}{c}\text { Customer } \\
\text { Satisfaction } \\
\text { (Y2) [9]and } \\
{[34]}\end{array}$} & $\begin{array}{l}\text { Satisfied With } \\
\text { the Overall } \\
\text { Services (Y2.1) } \\
{[9]}\end{array}$ \\
\hline & $\begin{array}{l}\text { Punctuality (X1.7) } \\
\text { [34] }\end{array}$ & & $\begin{array}{l}\text { Service Provider } \\
\text { Performance in } \\
\text { Line With } \\
\text { Expectations } \\
\text { (Y2.2) [9] }\end{array}$ \\
\hline & Cost (X1.8) [35] & & $\begin{array}{l}\text { Service provide } \\
\text { performance } \\
\text { that exceeds } \\
\text { expectations } \\
\text { (Y2.3) [9] }\end{array}$ \\
\hline \multirow{6}{*}{$\begin{array}{c}\text { Brand } \\
\text { Image (X2) } \\
{[28]}\end{array}$} & $\begin{array}{l}\text { Easy to Remember } \\
\text { (X2.1) [28] }\end{array}$ & & $\begin{array}{l}\text { Satisfied with } \\
\text { the overall } \\
\text { service quality } \\
\text { of employees } \\
\text { (Y2.4) [34] }\end{array}$ \\
\hline & $\begin{array}{l}\text { Full of Meaning } \\
(\mathrm{X} 2.2)[28]\end{array}$ & & \\
\hline & $\begin{array}{l}\text { Easy to Like (X2.3) } \\
\text { [28] }\end{array}$ & & \\
\hline & $\begin{array}{l}\text { Easy to Transfer to } \\
\text { Other Product Lines } \\
(\mathrm{X} 2.4)[28]\end{array}$ & & \\
\hline & $\begin{array}{l}\text { Easy to Develop } \\
(\mathrm{X} 2.5)[28]\end{array}$ & & \\
\hline & Protected (X2.6) [28] & & \\
\hline \multirow{6}{*}{$\begin{array}{l}\text { Social } \\
\text { media } \\
\text { marketing } \\
(\mathrm{X} 3)[36]\end{array}$} & $\begin{array}{l}\text { There is Interesting } \\
\text { and Entertaining } \\
\text { content (X3.1) [36] }\end{array}$ & & \\
\hline & $\begin{array}{l}\text { There is an } \\
\text { Interaction Between } \\
\text { The Customer and } \\
\text { The Service Provider } \\
\text { (X3.2) [36] }\end{array}$ & & \\
\hline & $\begin{array}{l}\text { Interaction Between } \\
\text { Customers (X3.3) } \\
{[36]}\end{array}$ & & \\
\hline & $\begin{array}{l}\text { Ease of Finding } \\
\text { Information (X3.4) } \\
{[36]}\end{array}$ & & \\
\hline & $\begin{array}{l}\text { Ease of } \\
\text { Communicating } \\
\text { Information to The } \\
\text { Public (X3.5) [36] }\end{array}$ & & \\
\hline & $\begin{array}{l}\text { The Level of } \\
\text { Customer Trust in } \\
\text { Services on Social } \\
\text { Media (X3.6) [36] }\end{array}$ & & \\
\hline
\end{tabular}

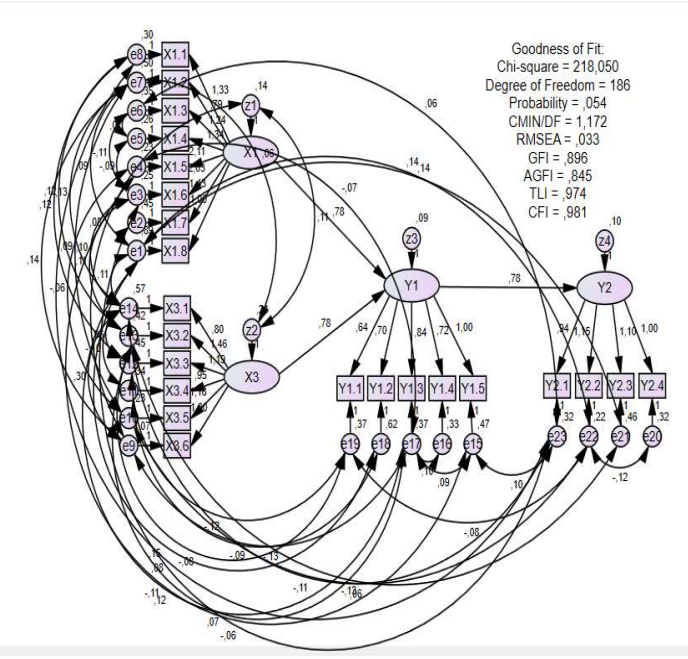

Fig. 3. Modification of the Exogen Variable

\section{c. Hypothesis 3}

H3: Social media marketing has a significant effect on usage decisions.

Based on the results of the study, the CR value was 11.779 and ttable was 1.714 (tcount $>$ ttable), so it was concluded that H1 in this hypothesis was accepted, where social media marketing had a significant effect with a regression coefficient value of 0.561 on the decision to use. This means that if social marketing increases by 1 unit, the decision to use the shipping industry will also increase by 0.561 .

This social media marketing does have a significant effect on usage decisions, but the results of the frequency distribution show that the "very satisfied" answer is below $50 \%$, which means that social media marketing is volatile and needs management attention. Given the fairly high correlation number $(0.561)$, if there is a shift towards insignificant influence, it will be fatal and cause considerable losses to management. The results of this study are in line with the research of [36] and [6].

\section{d. Hypothesis 4}

H4: The decision to use has a significant effect on customer satisfaction.

Based on table 3, the CR value is 11.779 and ttable is 1.714 (tcount $>$ ttable). So that in this hypothesis H1 is accepted, namely the use decision has a significant effect on customer satisfaction. The effect of usage decisions on customer satisfaction has a regression coefficient of 0.86 on customer satisfaction. This means that if the decision to use increases by 1 unit, the decision to use the shipping industry will also increase by 0.86 . The decision to use on customer satisfaction has a regression coefficient of 0.86 and from the results of the frequency distribution, the answers are very satisfactory, which is above $75 \%$, which means that the decision to use on customer satisfaction is sufficiently maintained and improved. The results of this study support the research of [37].

The processing of the second Measurement Model resulted in the Goodness of Fit and Cut-off Value, which 
were still not good. Modification of the Model. If the results of the Measurement Model are not good, then the results of the Structural Model processing are also not good. This is done to find a reference in modifying the model by knowing the modification index (MI). In order for Model Modification (Fig. 3) to produce the best Goodness of Fit and Cut-off Values, the numbers on the Covariance and Regression Weights must be large.

The results of the coefficient of the intervening variable on customer satisfaction have a fairly large value, namely the regression coefficient of 0.86 so that this company even though it is in a state of the covid pandemic, is still very promising and if the freight forwarding industry can handle the application of the modified results, it is possible to make another decision to use the delivery of goods and improve customer satisfaction. Respondents seem to still tolerate indicators of the late arrival of goods, limited communication about a delivery, and complaints of operator service quality, given the frequency distribution results that answered "very well" above $55 \%$. The equation model of the relationship of exogenous variables to the use and satisfaction of shipping service customers produces a mathematical equation that is very promising in this industry, namely $\mathrm{Y} 2=0.371 \mathrm{X} 1+0.482 \mathrm{X} 3$.

\section{Conclusion}

The results of the equation model for the relationship of exogenous variables to the use and satisfaction of shipping service customers are as follows, Y2 = $0.371 \mathrm{X} 1+0.482 \mathrm{X} 3$. Quality of Logistics Service has a positive and significant effect of 0.341 on the decision to use shipping services. The influence of brand image on usage decisions cannot be proven because there is multicollinearity, which causes these variables to be excluded from the study. Social media marketing has a positive and significant effect of 0.561 on the decision to use delivery services. The decision to use has a positive and significant effect of 0.86 on customer satisfaction with delivery services at the company "J\&T, JNE, TIKl, Wahana, SiCepat, ID Express and Pos Indonesia" which focuses on consumers who choose to shop through e-commerce.

\section{Reference}

[1] Asperindo. (2017). Melesat E-Commerce, Pertumbuhan Bisnis Kurir Kian Pesat.

[2] Adiprayitno, R dan Edwar M. (2017). Pengaruh Kualitas Layanan dan Harga Terhadap Keputusan Penggunaan Jasa pengiriman Barang JNE (Jalur Nugraha Ekakurir) di Agen Putro Agung Wetan Surabaya. Jurnal Pendidikan Tata Niaga. Vol. 01 Nomor 01.

[3] Nazelina, M., Novitasari, D., Fikri ,MA Ali, Asbari, M. (2020). Pengaruh Citra Merek, Harga Dan Kualitas Layanan Terhadap
Keputusan Konsumen Menggunakan Jasa Pengiriman. Jurnal Penelitian Rekayasa \& Manajemen industri (JIEMAR). Vol. 1 Nomor 3.

[4] Wijayanti, SED (2020). Pengaruh Harga dan Kualitas Pelayanan Terhadap Keputusan Penggunaan Jasa Pengiriman Barang: STudi Kasus pada Pengguna Jasa Pengiriman Makharya Cargo Surabaya. Skripsi. Universitas Islam Negeri Sunan Ampel Surabaya.

[5] Endriani, Dwi. (2018). Pengaruh Brand Image dan Kualitas Layanan terhadap Keputusan Pembelian Jasa dalam Prespektif Ekonomi Islam: Studi pada Pengguna Jasa J\&T Express di Bandar Lampung. Skripsi. Universitas Islam Negeri Raden Intan Lampung.

[6] Mileva, L. \& Fauzi, Achmad DH. (2018). Pengaruh Social Media Marketing Terhadap Keputusan Pembelian. Jurnal Administrasi Bisnis (JAB). Vol. 58 No. 1.

[7] Setiawan, Elfa. (2018). Pengaruh Citra Merek, Kualitas Produk, dan Persepsi Harga Terhadap Keputusan Menggunakan Jasa Kurir JNE, Agen JASAFA Jatiasih, Bekasi, Jawa Barat. Jurnal Transparansi. Vol.1, No.2, p.166-178.

[8] Li, Y., \& Kananurak, N. (2018). Faktor-Faktor yang Mempengaruhi Kepuasan Pelanggan Dan Loyalitas Merek Dari 5 Layanan Pengiriman Ekspres Terbaik Di Cina. UTCC International Journal of Business \& Economics, 10(2), p. 43-68.

[9] Hati, Shinta W., \& Juliati, Aisyah. (2019). Analisis Pengaruh Kualitas Layanan Logistik terhadap tujuan dan Loyalitas Pelanggan pada Perusahaan Logistik Jalur Nugraha Ekakurir (JNE). Jurnal Akuntansi, Ekonomi dan Manajemen Bisnis, Vol.2, No.7. p.240-249.

[10] Anwar, S, L. Min, G. Dastagir. (2019). Pengaruh Kualitas Layanan, Citra Merek, Nilai Persepsi Terhadap Kepuasan dan Loyalitas Pelanggan di Industri Perbankan Cina. Jurnal Internasional Pekerjaan Bisnis, Ekonomi dan Manajemen, 6 (3), p. 24-30.

[11] Japarianto, Edwin. (2018). Pengaruh Kualitas Layanan Logistik Terhadap Retensi Pelanggan Dengan Kepuasan Pelanggan Sebagai Variabel Intervininig Pada Industri Ekspedisi Laut Di Surabaya. Jurnal Manajemen Pemasaran, 12 (1).

[12] Rosyada, ZF Puspitasari, NB, Susanty, A., Andini, AR, Rumita, R. (2020). Analisis Kualitas Layanan Logistik untuk meningkatkan Kualitas Layanan Jasa Pengiriman JNE Express. Jurnal Teknik Industri. Vol. 5 (2).

[13] Ali, A, A. Melkonyan, B. Noche, T. Gruchmann. (2021). Mengembangkan Skala Kualitas Layanan Logistik Berkelanjutan untuk Penyedia Layanan Logistik di Mesir. Logistic $5(2)$ https://doi.org/10.3390/logistics5020021. 
[14] Kambiz \& Safoura, S. (2014). Pengaruh Brand Image Terhadap Kepuasan Konsumen dan Intensi Loyalitas (Studi Kasus: Konsumen Produk Hygine). Jurnal Internasional Inovasi \& Penelitian Teknik, 3 (1), p.2277-5668.

[15] Dam, S \& Dam, T. (2008). Hubungan Kualitas Layanan, Citra Merek, Kepuasan Pelanggan, dan Loyalitas Pelanggan. Jurnal Keuangan Asia, Ekonomi dan Bisnis. https://doi.org/10.13106/JAFEB.2021.Vol.8. Tidak. 3.0585.

[16] Suharsono, RS \& Sari, RP (2019). Pengaruh Promosi Media Online terhadap Keputusan Pembelian Produk Hijab (Studi Pada Alif Galeri Hijab Sidoarjo). Jurnal Aplikasi Manajemen dan Inovasi Bisnis. 1 (2), p.41-54

[17] Fajri, Deva \& Ma'ruf, JJ (2018). Sebagai Variabel Mediasi pada Maskapai Penerbangan Airasia di Banda Aceh. Jurnal Ilmiah Mahasiswa Ekonomi Manajemen. 3 (3).

[18] Gu, B., \& Ye, Q. (2013). Langkah Pertama di Media Sosial: Mengukur Pengaruh Tanggapan Manajemen Online terhadap Kepuasan Pelanggan. Manajemen Produksi dan Operasi, 23(4), 570-582.

[19] Hanasya, JR (2017). Dampak Social Media Marketing, Price Promotion, dan Corporate Social Responsibility Terhadap Kepuasan Pelanggan. Jurnal Penelitian Bisnis Jindal, Vol.6.

[20] Madni, GR. (2014). Perilaku Konsumen Dan Efektivitas Media Sosial. Jurnal Global Riset Manajemen dan Bisnis: E-Marketing, 14 (8).

[21] Serbetcioglu, C dan Göçer, A. 2020. Meneliti profil branding media sosial penyedia layanan logistik. Jurnal Pemasaran Bisnis \& Industri, 35 (12). https://doi.org/10.1108/JBIM-092019-0399

[22] Bilgin, Y., (2018). Pengaruh kegiatan pemasaran media sosial terhadap kesadaran merek, citra merek dan loyalitas merek. Studi Bisnis \& Manajemen: Sebuah Jurnal Internasional, 6(1), pp.128-148.

[23] Barykin, S, I. Kapustina, O. Kalinina, N. Kozlova, E. Ivanova, K. Borodina, V. Yadykin. (2021). Pendekatan Logistik Digital pada Mekanisme Sosial Ekonomi Layanan Energi, dalam Prosiding Penelitian Transportasi, 54.

[24] Indriyani, R., \& Suri, A. (2020). Pengaruh Media Sosial Terhadap Keputusan Pembelian Melalui Motivasi Konsumen pada Produk Fast Fashion. Jurnal Manajemen Pemasaran. 14 (1). p.25-34.

[25] Adyanto, B and Santosa, SB (2018). Pengaruh Kualitas Layanan, Brand Image, Harga dan Kepercayaan Produk Terhadap Keputusan Pembelian: Studi Layanan E-Commerce Berrybenka.com. Jurnal Manajemen Diponegoro. Vol.7 No.1.

[26] Utomo, H., Jonemaro EM, Ananta, MT (2017). Perbandingan Usabilitas Aplikasi Taksi
Online Android (Grab-Car Dan Uber) Menggunakan Unified Theory Of Acceptance And Use Of Technology (UTAUT). Jurnal Pengembangan Teknologi Informasi dan Ilmu Komputer Vol. 1, No. 12, hal.1708-1717.

[27] Nitisusastro, M. 2012. Perilaku Konsumen Dalam Perspektif Kewirausahaan. Bandung : Alfabeta.

[28] Kotler, P, \& Keller. (2012). Manajemen Pemasaran (edisi ke-14). New Jersey : Pearson Education, Inc.

[29] Jiang, H. dan Zhang, Y. (2016). Penyelidikan kualitas layanan, kepuasan pelanggan dan loyalitas di pasar maskapai China. Jurnal manajemen transportasi udara, 57, pp.80-88.

[30] Ghozali, Imam. 2009. Aplikasi Analisis Multivariat dengan Program SPSS. Semarang: UNDIP.

[31] Waluyo, M. \& Rachman, M. (2020). Mudah Cepat Tepat dalam Aplikasi Structural Equation Modeling Edisi Revisi. Batu : Literasi Nusantara.

[32] Gundono. (2015). Analisis Data Multivariat. Yogyakarta: BPF.

[33] Krisnawati, I. (2016). Pengaruh Kualitas Pelayanan, Promosi dan Harga Terhadap Keputusan Pembelian di J\&T Ekspress Cabang Nganjuk Tahun 2016. Jurnal SimkiEconomic, Vol. 01 Nomor 02.

[34] Versa, B., \& Subagio, H. (2014). Pengaruh Kualitas Pelayanan Logistik terhadap kepuasan pelanggan cat emco PT. Satriakarya Adiyudha (PT SKAY). Jurnal Manajemen Pemasaran Petra. Jilid 2, No 2. hal.1-9.

[35] Kahnali, RA, \& Esmaeili, A. (2015). Integrasi Dimensi SERVQUAL Dan Indikator Kualitas Layanan Logistik: Studi Kasus. Layanan Jurnal Internasional dan Manajemen Operasi, 21 (3), p.289-309.

[36] Khatib, F. (2016). Pengaruh Karakteristik Media Sosial Terhadap Keputusan Pembelian Studi Empiris Pelanggan Saudi Di Wilayah Aseer. Jurnal Internasional Bisnis Dan Ilmu Sosial, 7(4), p.41-50.

[37] Wulan, Wira S., Mawardi, MK, Pangestuti, E. (2016). Pengaruh Bauran Pemasaran Jasa Terhadap Keputusan Pembelian serta Dampaknya Terhadap Pelanggan: Studi pada Restoran Kayu Manis Tuban. Jurnal Administrasi Bisnis. 38 (2). p.176-182. 